[Vicino Oriente XXII (2018), pp. 185-195]

\title{
SOME NEWLY DISCOVERED ISLAMIC BUCKETS FROM GHAZNI (AFGHANISTAN)*
}

\author{
Valentina Laviola - University of Naples "L’Orientale"
}

\begin{abstract}
In 2012 an unexpected discovery occurred in Ghazni, where many Islamic buckets were retrieved fortuitously at the feet of the citadel. Only sixteen of them are nowadays preserved in the Kabul National Museum. These new artefacts come as a chance to complete our knowledge of the metalwork production from medieval Afghanistan.
\end{abstract}

Keywords: buckets; Ghazni; Islamic metalwork; Bobrinsky bucket; Khurasan

\section{A NEW DISCOVERY}

To unearth Islamic metalwork is quite an unusual event, given on one hand the absence of grave goods in the Islamic culture, and on the other, the cost of metal as a material, always needed for coinage and many other applications. Numerous metalwork, pertaining to any functional class, allegedly coming from Ghazni or purchased on Ghazni market are known. ${ }^{1}$ Some artefacts and fragments also emerged from the secular buildings - the royal palace $\left(11^{\text {th }}-12^{\text {th }}\right.$ century) and the so-called 'House of the Lusterware' (second half of the $12^{\text {th }}$ century) - excavated by the Italian Archaeological Mission in Afghanistan. ${ }^{2}$ Among them: three inkwells, ${ }^{3}$ six spoons, few vanity objects, little jewels, objects' fittings and two miniature objects.

Many years later, Ghazni still had a treasure to disclose. In 2012, an unexpected discovery occurred in the commercial area lying at the feet of the citadel. During restoration works into a shop, a huge number of buckets emerged from the floor by chance. ${ }^{4}$ An early witness reported that the items were up to one hundred. ${ }^{5}$ Unfortunately, only sixteen buckets reached the Kabul National Museum and there is no news about the many others. This regrettable episode comes as the last evidence of artefacts and archaeological finds disappearing in Afghanistan. However, let focus on the half-full glass, since the discovery of sixteen new metalwork, all belonging to the same class, is indeed a remarkable finding.

\footnotetext{
* This topic has been presented on occasion of the International Workshop "Khurasan: Land of the Rising Sun", held in the Linden-Museum of Stuttgart on November $3^{\text {rd }}-4^{\text {th }} 2016$.

1 It would be worthy to remind that the Italian Archaeological Mission in Afghanistan documented, between 1957 and 1978, many of the metalwork collections hosted in the country. A catalogue by the author is forthcoming: Islamic Metalwork from Afghanistan $\left(9^{\text {th }}-13^{\text {th }}\right.$ c.). The Italian Archaeological Mission Archives (1957-1978), Department of Asian, African and Mediterranean Studies, Series Maior, Naples.

2 For further information about the archaeological activities, see Bombaci 1959; Scerrato 1959a; Adamesteanu 1960.

See Laviola 2017 b.

4 Another metalwork hoard was found fortuitously in 1953, in Maimana (north-western Afghanistan): about thirty-two artefacts and fragments came out of a $t \bar{a} q$, a niche in a wall, where they had been probably hidden. The artefacts were delivered to the Kabul National Museum. See Scerrato 1964.

5 Philippe Marquise, then director of the Délégation Archéologique Française en Afghanistan (DAFA), reported the information.
} 
Some members of the Italian Mission happened to be in the right place at the right moment, and had the chance to see the objects, measure them and collect a complete photographic documentation. $^{6}$

\section{STATE OF PRESERVATION AND MANUFACTURING}

Once in the Kabul Museum, the buckets were cleaned from earthen incrustations, but no restoration has been performed yet. As far as we know, the objects are still in the Museum storage and have never been on exhibition; they have no inventory numbers as well. ${ }^{7}$

Each bucket still preserves its removable elements: the foot (or feet) and the handle, which most of times seem to pertain to the bodies they are joined to. Only buckets provided with three feet raise some doubt about the originality of such set up (see below). However, for the majority there is no apparent trace of interpolation or insertion of unrelated elements, thus the buckets should have not suffered any changing after manufacturing. ${ }^{8}$

The buckets have cast body and handle, with just one exception; ${ }^{9}$ the majority rests on a single foot, usually made of metal sheet, while two specimens rest on three small feet, cast and soldered to the underside.

The state of preservation varies: about six buckets are intact and in fair condition; they present only small gaps and dents. The remaining ten are, instead, in a poor condition: wide portions of the body lack and long deep cracks split across it. Many have a thick, usually greenish patina, which covers small or extended areas of the surface, sometimes making the decorative and epigraphic details barely recognizable.

Engraving is the main decorative technique adopted, realized on different layers of depth. Engraving and chiselling are also the first steps for the inlay, executed most of times with copper employed in thick wires or foils. Just on one specimen, silver is employed in thin wires. Thanks to its brighter colour, the inlay lights up the decorative features even on very dark surfaces. Unfortunately, the inlay is particularly affected by losses and damages. Some of its original slots remain empty: this circumstance turns out to be useful, since it consents to recognize the decorative design or the epigraphical content even on damaged objects.

\section{A MAIN MODEL AND SOME UNIQUE SPECIMENS}

The buckets show five different morphological models. The sub-globular body represents the main model, attested in twelve items out of sixteen; single specimens attest other four models: two three-footed and two footless.

$6 \quad$ All the pictures belong to the Italian Mission archives. I wish to thank Roberta Giunta, deputy director of the Italian Mission and director of the Islamic Ghazni Archaeological Project, who gave me full access to unpublished metalwork and shared with me her first impressions. I also express my gratitude to Dr Omara Khan Massoudi, former Director of the Kabul National Museum, who let this newly discovered material to be photographed and studied. A catalogue of the sixteen buckets is in preparation by the author.

7 In this paper, they are numbered from 1 to 16 following the order of documentation. Pictures of only six buckets are attached to show the morphological models.

8 The author had no chance to observe the objects directly, thus opinions on their status are based on pictures and on the report given by Roberta Giunta.

9 See below the cylindrical bucket no. 2 . 


\subsection{Sub-globular buckets}

Sub-globular buckets rest on a high trumpet-shaped foot; they measure on average about $17 \mathrm{~cm}$ in height, $18 \mathrm{~cm}$ in diameter, ${ }^{10}$ and $2 \mathrm{~kg}$ in weight. The rim is either flared, in seven specimens, ${ }^{11}$ or broad and flat, in five specimens ${ }^{12}$ (figs. 1-2). Both kinds of rim host a decoration (see below). The handle is massive, square-sectioned and moulded in a series of geometrical solid forms; usually, it is pierced at its centre to host a spike, so that the bucket could be hung. The handle has pincer-shaped terminals, adorned at their top by zoomorphic protomes (felines ${ }^{13}$ or birds ${ }^{14}$ ) carved in bas-relief, which clamp the vertical lugs welded on the rim. About five cases show a second rate version of this handle: ${ }^{15}$ the section is thinner, with roughly defined mouldings; the protomes are highly stylized and reduced to a geometric profile.

The decoration usually involves every part of the bucket: foot, body and handle. The trumpet-shaped foot usually bears an engraved decoration of geometrical kind. The handle, beyond the already mentioned mouldings, can bear a geometric pattern on the outer side of the arch. Body decoration always distributes horizontally in three or four registers. The space is calculated precisely to insert the decorative elements, which are always evennumbered. Sometimes the design used in one register is repeated in another one, employing a doubled number of elements. All patterns are framed into roundels, arches or cartouches; no free representation is admitted. ${ }^{16}$

Roundels are the most common kind of frame: their margin can be simply engraved or inlaid with copper; some also host an inlaid crescent. The latter are typically employed to divide the epigraphical bands in sections. Arches also appear frequently in the pointed, trilobed and five-lobed version. The element boasts a long tradition in the Afghan area since the Buddhist period. ${ }^{17}$ In Islamic time, the trilobed arch became a peculiar feature, since its first employment on Maḥmud's tomb in Rawza (Ghazni) and then recurring on many materials. ${ }^{18}$ Rectangular cartouches, with concave short sides, enclose inscriptions or walking animals. A bigger kind of cartouches, defined by inlaid intertwined ribbons, enclose series of two or three roundels to host the zodiac signs. ${ }^{19}$ Narrow trapezoidal cartouches appear of the buckets rim, alternated to typically Iranian elements such as the seven-disc rosette and the eight-petal flower. ${ }^{20}$

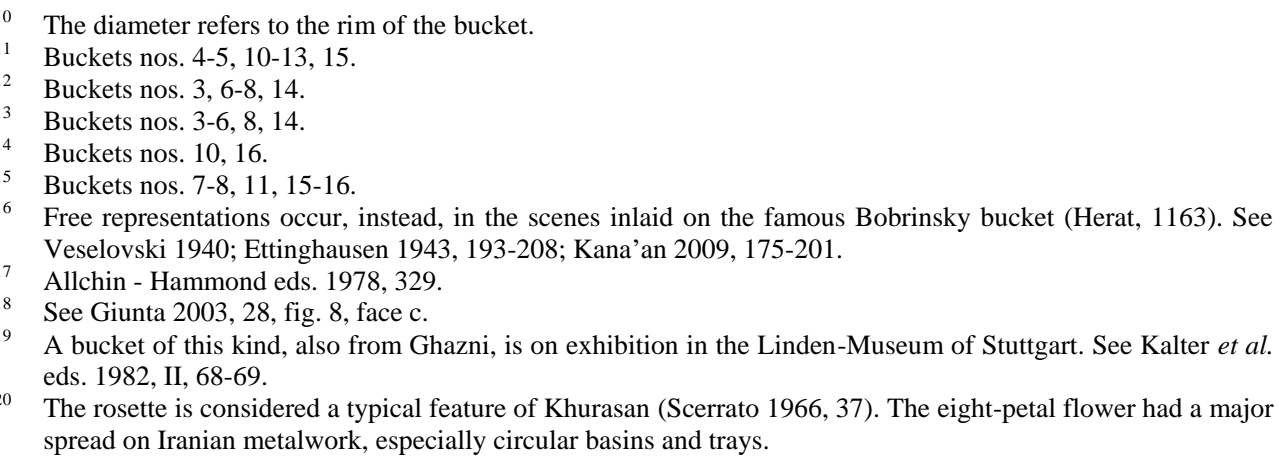


Other attested decorative elements belong to the typical repertoire of Eastern Iranian metalwork. Among them: the floriated vase $;^{21}$ intertwined semi-circular arches, enriched by an upturned trilobed flower, that recur on the lower body of buckets; a six-pointed star pattern composed by interlacing ribbons, included in big roundels; the so-called 'Solomon knot' (or Central Asian good-wishing knot) into roundels. The human figure, instead, never appears. $^{22}$

Zoomorphic elements include real and fantastic animals: especially birds of different species, singles or in pairs, framed into arches and roundels, but also running quadrupeds, in pairs, into cartouches; harpies are the most common fantastic animals, framed into arches and roundels, while sphinxes appear only in one case, in alternation to harpies. ${ }^{23}$

Other figurative representations concern the zodiac signs, attested on four buckets. ${ }^{24}$ The theme is largely spread on Islamic, and especially Iranian, metalwork. ${ }^{25}$ Astrological figures were believed to play a good-wishing, talismanic role. Unfortunately, the engraved signs are generally in a bad state of preservation, so that just few of them are still visible. On Ghazni buckets, the signs are portrayed on their own, without their Lord planet as often occurs according to the domicilia system. $^{26}$

Sub-globular buckets bear three inscriptions on the body, while no epigraphy has been noticed on the handle. ${ }^{27}$ Inscriptions stand against an engraved vegetal background declined in a number of varieties that attests the care devoted to it. Kufic and cursive scripts are employed on the same object, generally according to precisely assigned locations: Kufic on the lower body and the rim, cursive on the upper body. The latter inscription enjoys the most visible position; usually it is inlaid with copper and is split in four sections by as many roundels. ${ }^{28}$

Arabic is the only language, as traditionally occurs in standard benedictory texts. The starting expression of the $d u^{\prime} \bar{a}^{\prime}$ depends on the script: bi-l-yumn wa'l-baraka is adopted in Kufic ones, al- 'izz wa'l-iqbāl in cursive ones. The closing formula al-baqa'), wishing eternal life, always lacks the final hamz $\bar{a}^{\prime}$. Not always, it is followed by the dedication $l i-$ $s \bar{a} h \operatorname{hibi}$-hi to an anonymous owner. Benedictory terms always have the article and they rarely appear in a shortened form.

\subsection{Three-footed buckets}

Two buckets rest on three small feet: it is unclear whether these feet replaced a lost original foot or they were meant to be this way from the very first moment. Bucket no. 9

21 Three vases showing the same shape of those represented on metalwork were documented in Kandahar and the Rawza Museum (see Scerrato 1959b, 102, no. 3, figs. 8a-b; Melikian-Chirvani 1975, 202-204, figs. 13$15)$.

22 The absence of anthropomorphic figures marks another difference with the Bobrinsky bucket and some other Iranian buckets as well.

Bucket no. 7 .

Buckets nos. 3, 6, 11, 15 .

Scerrato 1961, 162; Fehérvári 1976, 73-74

26 See for example the 'Wade Cup' of the Cleveland Museum of Art (Rice 1955, 17-20). See also Scerrato 1981.

The Bobrinsky bucket bears engraved in such position the date and place of manufacturing.

28 Buckets nos. 3, 7-8, 11, 13, 15-16. 
has reduced size (h. $14.5 \mathrm{~cm}, \varnothing 16.7 \mathrm{~cm}, 1 \mathrm{~kg}$ ), bulbous body and a slightly flared rim, so thin to prevent any decoration (fig. 3). The handle, very thin and simple, has a square section along the arch, but it becomes round in the terminals that remain open after passing through the lugs.

The object is in a poor condition, affected by many gaps and cracks. The decoration, engraved and quite simple, consists of three horizontal registers: bottom-up, a narrow geometrical strip, a sequence of running hares and hunting dogs, and an epigraphical band. The second register bears on the background a series of big spiral vegetal scrolls, enriched by buds, half-palmettes and trilobed flowers. Both the vegetal and zoomorphic patterns are executed on a macroscopic scale in respect to other buckets. The dogs are portrayed with an open mouth and wear a collar. ${ }^{29}$ The inscription in the third register runs against a vegetal background, expressing a standard $d u^{\prime} ' \bar{a}$ '. The hunting scene would point to an early date. Among the already published buckets, there are some specimens similar in shape, size and decorative design, which are usually assigned to the $11^{\text {th }}$ century Khurasan. ${ }^{30}$

Bucket no. 1 (h $18.2 \mathrm{~cm}, \varnothing 19 \mathrm{~cm}, 2.05 \mathrm{~kg}$ ) presents an almost spherical body and a straight rim, too thin to host a decoration on its top (fig. 4). The handle has sinuous curving terminals, with a knob finial; at its centre, a globular element with a nailed arch-shaped ring is inserted. The object is in fair condition; one of the feet, still preserved, is detached from the body. The bucket is undecorated, except for a single horizontal register running below the rim. The engraved benedictory inscription, in cursive, lies against a vegetal background composed by two intertwined foliated scrolls, which run mainly above letters and seem to originate from a double palmette. The text has revealed quite interesting: the good-wishing terms are deprived of the article - this being a unique feature among the group of Ghazni buckets - and the name of the owner is actually expressed. The inscription is still under analysis, but up to now, a religious epithet has been deciphered. It would indicate a personality out of the court's milieu. ${ }^{3}$

The bucket stands as a unique object, because of its shape, decorative scheme, vegetal pattern and epigraphical band. Its chronology remains an open issue.

\subsection{Footless buckets}

Bucket no. 12 (h $13.2 \mathrm{~cm}, \varnothing 19.2 \mathrm{~cm}, 1.5 \mathrm{~kg}$ ) presents a hemispherical bottom and straight wall with no rim (fig. 5). The surface is raw and completely undecorated. It was clearly a humble object.

Bucket no. 2 has a cylindrical body with flared rim (fig. 6). The object (h $14.6 \mathrm{~cm}, \varnothing$ $19.7 \mathrm{~cm}, 1.1 \mathrm{~kg}$ ) is considerably lighter than the majority of buckets and most probably made of metal sheet. The thinness of the wall has resulted in extended damages. The tapering handle is joined to the lugs through a button-shaped bolt and is pierced in the centre. The body surface is covered by a gold-greenish patina, which hides most part of the

29 Hunting dogs wearing golden collars are attested in the sources about the Seljuq (see Laviola 2017a, 206).

30 See Ward 1993, 59, fig. 42

31 Few names of recipients are known from Islamic metalwork and even less not belonging to rulers (see Laviola 2017c, 113). The Bobrisnky bucket represents one of these rare examples: a luxurious metalwork explicitly made for a bourgeois, a merchant. 
decoration. Two registers are engraved below the rim, both showing a dotted background. The first bears a geometrical 'chain-pattern'; in the second register runs an inscription in Kufic with scrolls ending in trilobed flowers over the letters. Unfortunately, only a very short portion of the text is still visible, so to make it unreadable.

This specimen resembles closely some already published buckets coming from Fayyum (Egypt), which show two engraved (and never inlaid) registers on the upper body, with a foliated Kufic inscription. They are datable to the $10^{\text {th }}-11^{\text {th }}$ century. ${ }^{32}$

\section{OPEN ISSUES AND FUTURE PERSPECTIVES}

Many Islamic buckets have been published so far (more than eighty coming from Khurasan), ${ }^{33}$ but until now they were extremely under-represented in Afghan collections. The wide metalwork documentation gathered by the Italian Archaeological Mission (19571978) included not a single specimen; nowadays, one sub-globular bucket - unrelated to the group from Ghazni - is on exhibition in the Kabul National Museum ${ }^{34}$ and none in the Herat National Museum. The new hoard brought to light comes to bridge this gap; it will certainly offer the occasion to summarize the standing knowledge and prove some hypothesis.

The first issue to discuss is the buckets provenance. Such a fortuitous finding raises some doubts of course, but the huge number of specimens retrieved would indicate an atelier more likely than just a shop. The finding location, the feet of Ghazni citadel, makes the discovery even more important, placing the objects in a historically relevant set.

The group of artefacts has revealed extremely interesting: a high variety of models is attested and different qualitative levels in manufacturing as well. All buckets could have been produced locally or some specimens could have been imported from abroad. Hypothesis are tentative at this stage of research.

On the base of a brief comparison with other known buckets and taking into account the decorative patterns in common with other Iranian metalwork, the main group of subglobular buckets could be generally assigned to the $12^{\text {th }}-13^{\text {th }}$ century. Of course, a deeper analysis will clarify the peculiarity of each specimen, bringing to a more precise attribution. Certainly, comparison should not be limited only to other buckets or metalwork: other materials coming from Ghazni, such as the marbles, could prove useful from both an epigraphical and iconographical point of view.

Another issue to examine is what relation exists between Ghazni buckets and the already known ones. The majority of the latter are generally attributed to Khurasan, a regional definition that proves more than ever vague talking about metalwork. The Bobrinsky bucket, which is actually coming from a city of Khurasan, Herat - taking for granted the truthfulness of its inscription - cannot be farer from Ghazni buckets on a stylistic ground with its lavish opulence. Six registers filled by free continuous representations, including many human figures; a massive display of copper and silver inlay; many information given by the epigraphy, inscribed even on the handle; the use of

Fehérvári 1976, 47-48, nos. 24, 26, pl. 8:b, d; Ward 1993, 65, fig. 48

Ivanov $2004,172$.

See Laviola 2016, 112, 496 
Persian language and human-headed script. Ghazni buckets, instead, favour order and balance in the decoration, an alternation of empty and full spaces precisely arranged. The inlay is limited to margins of frames, inscriptions and single decorative elements; it is never employed as a ground covering technique. Standard inscriptions, limited to the Arabic language, are integrated in the decorative design. Perhaps, research going further, a distinction between Eastern Iranian and Khurasanian buckets will be identified.

Certainly, this new discovery comes to remind that Ghazni has still a lot to tell; a thorough study of the metalwork coming from the city would probably lead to demonstrate a major production, going beyond the generic definition of Khurasan.

\title{
REFERENCES
}

\author{
Adamesteanu, D. \\ $1960 \quad$ Notes sur le site archéologique de Ghazni: Afghanistan 15/1 (1960), pp. 21-30. \\ ALlChIN, F.R. - HAMMOND, N. (eds.) \\ 1978 The Archaeology of Afghanistan from Earliest Times to the Timurid Period, London - \\ New York - San Francisco 1978. \\ BOMBACI, A. \\ 1959 Introduction to the Excavations at Ghazni. Summary Report on the Italian Archaeological \\ Mission in Afghanistan: East and West 10 (1959), pp. 3-22. \\ ETTINGHAUSEN, R. \\ 1943 The Bobrinsky 'Kettle’: Gazzette des Beaux Arts 24 (1943), pp. 193-208. \\ FEHÉRVÁRI, G. \\ 1976 Islamic Metalwork of the Eighth to the Fifteenth Century in the Keir Collection, London \\ 1976. \\ GIUNTA, R. \\ 2003 Les inscriptions funéraires de $\dot{G} a z n \bar{\imath}$ (IV-IX/X-XV siècles) (Università degli Studi di \\ Napoli "L'Orientale" - Is.I.A.O. - Fondation Max van Berchem - Series Maior 8), Naples \\ 2003. \\ IVANOV, A.A. \\ 2004 A Second 'Herat Bucket' and Its Congeners (transl. J.M. Rogers): Muqarnas 21 (2004), \\ pp. 171-179. \\ KALTER, J. - VON FriedRich Kussmaul, B. - Luschey, H. (eds.) \\ 1982 Ferne Völker-Frühe Zeiten. Kunstwerke aus dem Linden-Museum Stuttgart. II, Orient, \\ Südasien, Ostasien, Recklinghausen 1982. \\ KANA'AN, R. \\ 2009 The de Jure 'Artist' of the Bobrinsky Bucket: Production and Patronage of Metalwork in \\ pre-Mongol Khurasan and Transoxiana: Islamic Law and Society 16/2 (2009), pp. 175- \\ 201. \\ LAVIOLA, V. \\ 2016 Metalli islamici dai territori iranici orientali (IX-XIII sec.). La documentazione della \\ Missione Archeologica Italiana in Afghanistan, $\mathrm{PhD}$ thesis, "Ca' Foscari" University of \\ Università di Venezia (unpublished), 2016, http://hdl.handle.net/10579/8349. \\ 2017a Drinking from a Golden Cup, Eating from a Silver Dish. Metalwork in Islamic Iranian \\ Sources (11 ${ }^{\text {th }}-12^{\text {th }}$ century): Annali dell'Istituto Orientale di Napoli (s. Or.) 77 (2017), pp. \\ $181-214$.
}


2017b Three Islamic Inkwells from Ghazni Excavation: Vicino Oriente XXI (2017), pp. 111126.

2017c Artisans Signatures from Pre-Mongol Iranian Metalwork: An Epigraphic and Palaeographic Analysis: Eurasian Studies 15/1 (2017), pp. 80-124.

MELIKIAN-CHIRVANI, A.S.

1975 Les bronzes du Khorassan - III: Bronzes inédit du Xe et du XIe siècle: Studia Iranica 4 (1975), pp. 187-205.

RICE, D.S.

1955 Studies in Islamic Metal Work - V: Bulletin of the School of Oriental and African Studies 17/2 (1955), pp. 206-231.

SCERRATO, U.

1959a The First two Excavation Campaigns at Ghazni, 1957-1958. Summary Report on the Italian Archaeological Mission in Afghanistan: East and West 10/1-2 (1959), pp. 23-55.

1959b Oggetti metallici di età islamica in Afghanistan. I: Antiquario di Kandahar: Annali dell'Istituto Orientale di Napoli s.n. 9 (1959), pp. 95-130.

1961 Problemi di storia e d'arte dell'Afghanistan islamico: G. GuLlini (ed.), L'Afghanistan dalla Preistoria all'Islam. Capolavori del Museo di Kabul, Torino 1961, pp. 59-68.

1964 Oggetti metallici di età islamica in Afghanistan. II. Il ripostiglio di Maimana: Annali dell'Istituto Orientale di Napoli s.n. 14/2 (1964), pp. 673-714.

1966 Metalli islamici, Milano 1966.

1981 Lo zodiaco e i pianeti del bacino 58-2-56 del Museo di Kabul: La Bisaccia dello Skeikh. Omaggio ad Alessandro Bausani nel sessantesimo compleanno (Quaderni del Seminario di Iranistica, Uralo-Altaistica e Caucasologia dell’Università degli Studi di Venezia 19), Venezia 1981, pp. 29-243.

VESELOVSKI, N.I.

1940 The Herat Bronze Bucket of 559 AH (1163 CE) from the Collection of Count A.A. Bobrinsky, St. Petersburg 1940.

WARD, R.

1993 Islamic Metalwork, London 1993. 


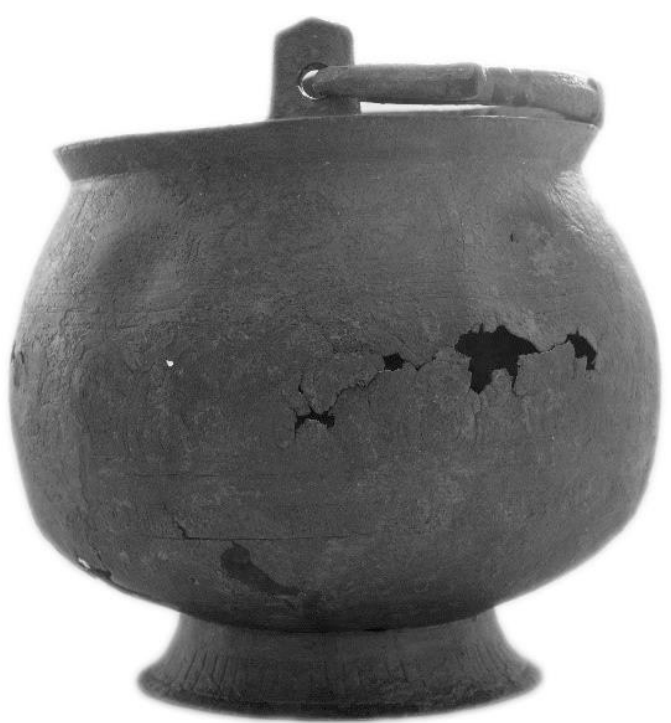

Fig. 1 - Sub-globular bucket with flared rim, no. 10 (Italian Archaeological Mission archives).

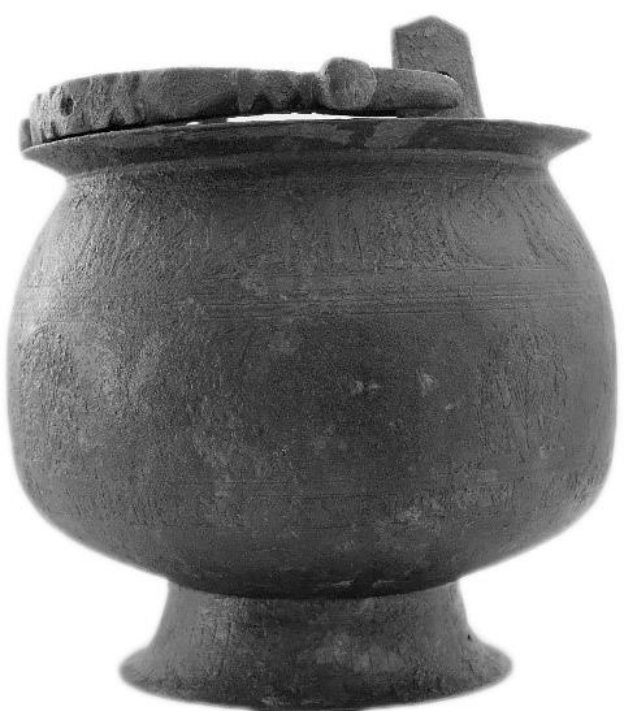

Fig. 2 - Sub-globular bucket with broad and flat rim, no. 14 (Italian Archaeological Mission archives). 


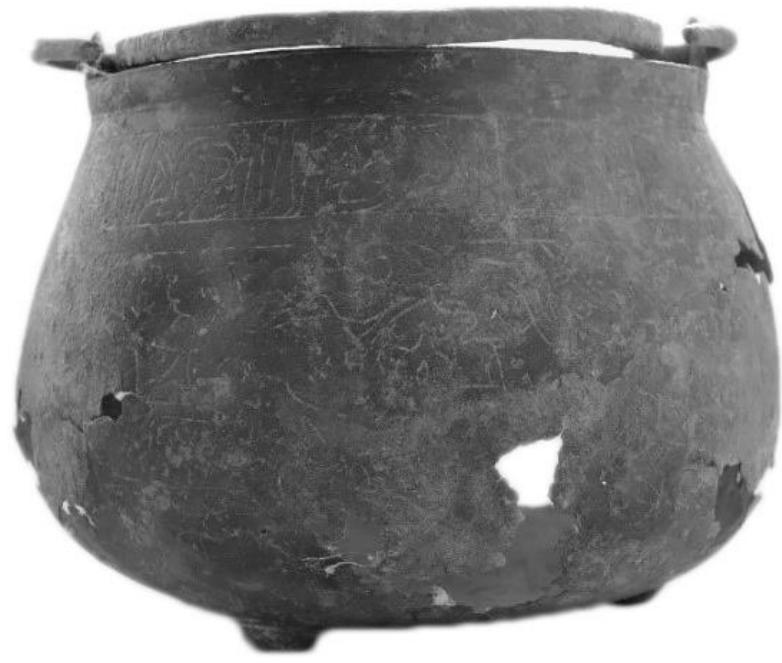

Fig. 3 - Bulbous bucket, no. 9 (Italian Archaeological Mission archives).

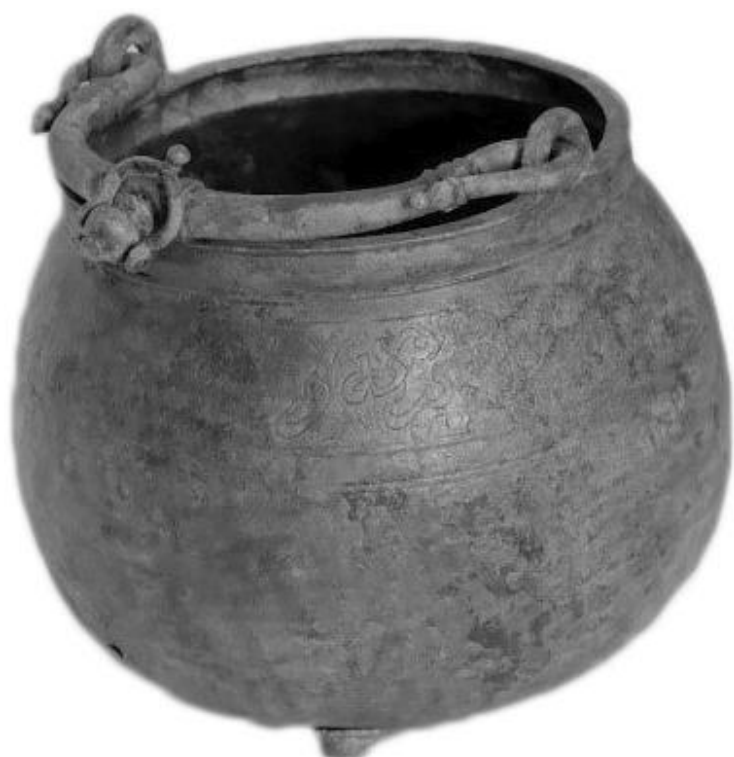

Fig. 4 - Almost spherical bucket, no. 1 (Italian Archaeological Mission archives). 


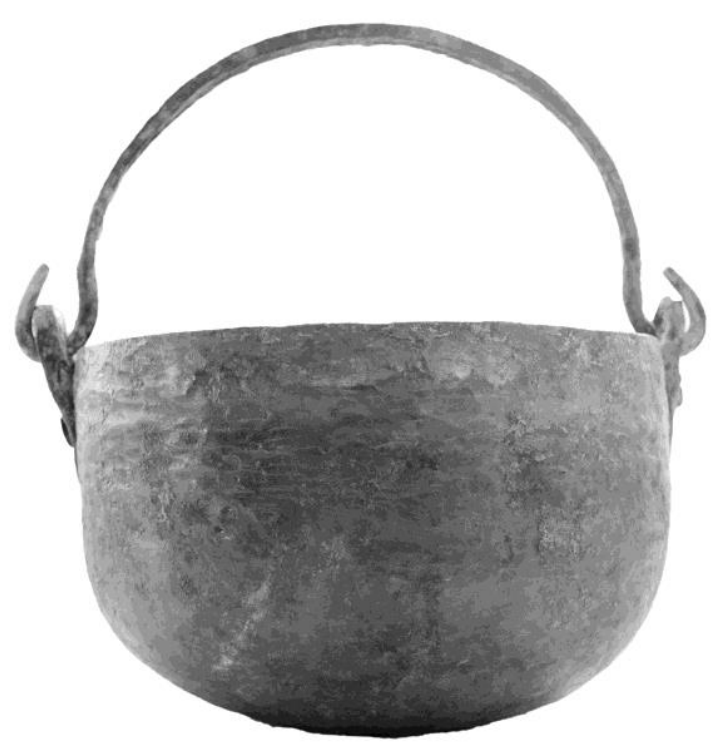

Fig. 5 - Bucket with hemispherical bottom, no. 12 (Italian Archaeological Mission archives).

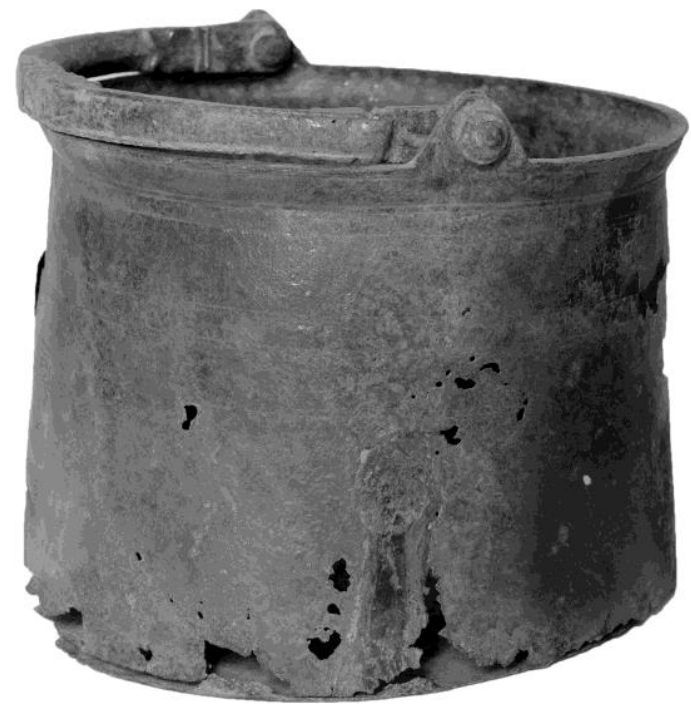

Fig. 6 - Cylindrical bucket, no. 2 (Italian Archaeological Mission archives). 